\title{
On the antibacterial effects of manuka honey: mechanistic insights
}

This article was published in the following Dove Press journal:

Research and Reports in Biology

29 October 2015

Number of times this article has been viewed

\section{Aled Edward Lloyd \\ Roberts* \\ Helen Louise Brown* \\ Rowena Eleri Jenkins}

Department of Biomedical Sciences, Cardiff Metropolitan University,

Cardiff, Wales, UK

*These authors contributed equally to this work
Correspondence: Rowena Eleri Jenkins

Department of Biomedical Sciences,

Cardiff Metropolitan University,

Western Avenue, Cardiff CF5 2YB,

Wales, UK

Tel +442920205996

Email rojenkins@cardiffmet.ac.uk
Abstract: Antimicrobial resistance (AMR) is an increasing clinical problem precipitated by the inappropriate use of antibiotics in the later parts of the 20th Century. This problem, coupled with the lack of novel therapeutics in the development pipeline, means AMR is reaching crisis point, with an expected annual death rate of ten million people worldwide by 2050 . To reduce, and to potentially remedy this problem, many researchers are looking into natural compounds with antimicrobial and/or antivirulence activity. Manuka honey is an ancient antimicrobial remedy with a good track record against a wide range of nosocomial pathogens that have increased AMR. Its inhibitory effects are the result of its constituent components, which add varying degrees of antimicrobial efficacy to the overall activity of manuka honey. The antimicrobial efficacy of manuka honey and some of its constituent components (such as methylglyoxal and leptosperin) are known to bestow some degree of antimicrobial efficacy to manuka honey. Despite growing in vitro evidence of its antimicrobial efficacy, the in vivo use of manuka honey (especially in a clinical environment) has been unexpectedly slow, partly due to the lack of mechanistic data. The mechanism by which manuka honey achieves its inhibitory efficacy has recently been identified against Staphylococcus aureus and Pseudomonas aeruginosa, with both of these contrasting organisms being inhibited through different mechanisms. Manuka honey inhibits $S$. aureus by interfering with the cell division process, whereas $P$. aeruginosa cells lyse in its presence due to the reduction of a key structural protein. In addition to these inhibitory effects, manuka honey is known to reduce virulence, motility, and biofilm formation. With this increasing in vitro dataset, we review the components and our mechanistic knowledge of manuka honey and how manuka honey could potentially be utilized in the future to impact positively on the treatment of microbial, resistant infections.

Keywords: Staphylococcus aureus, Pseudomonas aeruginosa, biofilm, antibiotic resistance

\section{Introduction}

\section{The problem of antibiotic resistance}

The ability of bacteria to adapt and become resistant to antibiotics has been recognized by the scientific community for many decades. Staphylococcus aureus, ${ }^{1}$ Acinetobacter baumannii, ${ }^{2}$ and Enterococci species $^{3}$ are just some of the nosocomial pathogens with increased antimicrobial resistance (AMR) that cause difficult-to-treat infections worldwide. AMR is commonly accrued through genetic changes, which confer a more resistant phenotype on the cell, or through the integration of the cell into a biofilm, which can lead to a transient increase in tolerance to antibiotics of up to 1,000 -fold. ${ }^{4}$ The biofilm phenotype is commonly found in urinary tract infections, ${ }^{5}$ multi-species chronic otitis media, ${ }^{6,7}$ and Pseudomonas aeruginosa infections in both burns ${ }^{8}$ and the cystic fibrosis lung. ${ }^{9}$ The prolonged over- and misuse of antibiotics, ${ }^{10}$ dwindling antibacterial 
development, ${ }^{11}$ and lack of funding for novel therapeutic research ${ }^{12}$ has allowed AMR to reach crisis point.

AMR infections are a major health care burden, leading to increased morbidity, mortality, and treatment costs. ${ }^{13}$ A recent study estimated the total cost of an AMR infection at between US $\$ 70,000$ and US $\$ 100,000$ per person. ${ }^{14}$ However it has been suggested that the cost of AMR could be much higher as routine operations, which require prophylactic use of antibiotics (eg, cancer therapy and joint/ organ replacements) would also be affected. ${ }^{15}$ Recently, initiatives that are designed to stimulate novel therapeutic development, such as the Longitude prize, have been instigated; however, compounds from these initiatives will not be available for several years, due to the inherent lag time in the development process.

To address the issue of AMR in the short term, researchers have generally taken one of two approaches: 1) recombining existing antimicrobial formulations to produce novel combinations; or 2) investigating alternative treatment therapies, while restricting the use of antimicrobial agents that are still currently effective. ${ }^{16}$ Many of these therapies have shown promise, as they provide a broad spectrum of activity, targeting multiple cellular processes and therefore reducing the likelihood of AMR arising. ${ }^{17-20}$ Some of the alternative antimicrobial therapies investigated include nanoparticles, ${ }^{21}$ bacteriophage "cocktails", ${ }^{22}$ and natural substances such as honey. ${ }^{23,24}$

\section{Honey as an antimicrobial}

Honey has been used for many centuries as a sweeter, food preservative, and therapeutic product. ${ }^{25}$ It is produced by honey bees (Apis mellifera) and is formed by ripening nectar, honeydew, and bee secretions. ${ }^{26}$ Honey can contain over 200 compounds, ${ }^{27}$ being broadly comprised of sugars, amino acids, vitamins, minerals, enzymes, flavonoids, phenolic acids, and antioxidants. ${ }^{28}$ The exact composition of honey differs depending on the plants foraged by the bees, environmental conditions, and downstream processing. ${ }^{29}$ In ancient times, medical treatises described how different honeys should be selected for different ailments, ${ }^{30}$ and scientific evidence is now emerging that also supports the careful selection of honeys for medical use. ${ }^{30}$ For example, honeys that are darker in color, such as manuka and buckwheat, have higher antioxidant activity than lighter honeys. ${ }^{31}$ Honey is reported to have immunomodulatory, ${ }^{32}$ antidiabetic, ${ }^{33,34}$ antitumor, ${ }^{35}$ antifungal, ${ }^{36}$ antiviral, ${ }^{37}$ and antibacterial properties. ${ }^{23,38-40}$ A brief summary of the historical and modern medical claims for use of honey can be found in Table 1 .
There has been a renewed interest in using honey, in particular manuka honey, to treat bacterial infections, especially those with AMR characteristics. ${ }^{78}$ This interest is due to an increasing amount of evidence reporting the successful use of honey in the treatment of topical infections, some of which are not responsive to conventional treatments. ${ }^{46,79}$ Several in vitro studies have reported that manuka honey has a synergistic activity when combined with antibiotics such as oxacillin, ${ }^{80}$ rifampicin, ${ }^{52}$ and vancomycin. ${ }^{55}$ In addition, honey can be used for prolonged treatments due to its low toxicity, ${ }^{35,81}$ and to date, little bacterial resistance to honey has been reported. ${ }^{82}$

Despite the apparent benefits of honey for the management of infection, its use is not currently widespread in the developed world. The poor uptake by clinicians ${ }^{47}$ is due in part to a lack of scientific data pinpointing the mode of action against pathogens of interest. ${ }^{27}$ To combat these concerns, the past two decades have seen the number of research groups and the number of papers published on honey steadily rise, with studies focusing on the identification of active components, mode of action, and clinical efficacy of honey. Herein, we review the current understanding of these aspects, with a focus on manuka honey due to its perceived enhanced antimicrobial activity (compared to other honey types), and

Table I Summary of medical claims, both historical and modern, which have been attributed to honey

\begin{tabular}{|c|c|c|}
\hline Timeframe & Claim & References \\
\hline \multirow[t]{5}{*}{ Historical } & $\begin{array}{l}\text { Wound salve (Roman, Egyptian, Assyrian, } \\
\text { Chinese, and Greek texts all reference } \\
\text { the use of honey to treat wounds) }\end{array}$ & 41,42 \\
\hline & $\begin{array}{l}\text { Treatment of gut diseases } \\
\text { (diarrhea and constipation) }\end{array}$ & 41 \\
\hline & Pain relief & 41 \\
\hline & Control of acute fever & 41 \\
\hline & Treatment of eye infection & 43 \\
\hline \multirow[t]{12}{*}{ Modern } & $\begin{array}{l}\text { Control of infection in wounds (including } \\
\text { surgical, ulcerated, and burn wounds) }\end{array}$ & $39,42,44-49$ \\
\hline & $\begin{array}{l}\text { Treatment of multidrug-resistant } \\
\text { topical infections }\end{array}$ & $50-52$ \\
\hline & Treatment of bacterial biofilm infections & $53-61$ \\
\hline & $\begin{array}{l}\text { Treatment of bacterial gut infections } \\
\text { (ie, Helicobacter pylori, Clostridium difficile) }\end{array}$ & $56,62,63$ \\
\hline & Promotion of faster wound healing & $64-66$ \\
\hline & Wound debridement & 67,68 \\
\hline & $\begin{array}{l}\text { Decreased duration of diarrhea and } \\
\text { gastroenteritis }\end{array}$ & 69,70 \\
\hline & Conjunctivitis & 44 \\
\hline & Treatment of cancer & 35,71 \\
\hline & $\begin{array}{l}\text { Alleviation of chemotherapy treatment } \\
\text { symptoms }\end{array}$ & $72-74$ \\
\hline & Decreased inflammation & 75,76 \\
\hline & Reduction of Crohn's disease symptoms & 77 \\
\hline
\end{tabular}


since it is already a licensed medical product in Australia, New Zealand, the UK, Europe, Canada, and US. ${ }^{83}$

\section{Components of honey with antimicrobial activity}

Defining the precise cause of the antimicrobial activity seen in honey is complicated due to the multifactorial nature of honey. Honeys have high osmolality due to the high concentration of sugars, ${ }^{29}$ and it has been shown that $61 \%$ of honeys tested have antibacterial activity, which can be attributed solely to their high osmotic potential. ${ }^{30}$ In addition to this feature, the majority of non-manuka honeys' antimicrobial activity is derived from the production of hydrogen peroxide $\left(\mathrm{H}_{2} \mathrm{O}_{2}\right)$ upon dilution and subsequent generation of reactive oxygen species. ${ }^{84}$ Although the activity generated by $\mathrm{H}_{2} \mathrm{O}_{2}$ is potent, that activity can be curtailed by catalase. ${ }^{85}$ In a wound environment, where catalase is commonly released from human tissue, this curtailment leads to reduced antimicrobial activity of the honeys, therefore raising doubts over their use in a clinical setting. Other components such as immune modulatory molecules, eg, bee defensin $1,{ }^{85}$ phenolics, ${ }^{86,87}$ and flavonoid compounds, ${ }^{88}$ also contribute to activity in some honeys.

The antimicrobial activity of manuka honey is not $\mathrm{H}_{2} \mathrm{O}_{2}-$ based; thus far, however, the constituents responsible for its activity have not yet been fully elucidated. ${ }^{89}$ To date, both methylglyoxal (MGO) and leptosperin have been identified as major contributors to its enhanced antimicrobial activity. ${ }^{90,91}$ An overview of the active components of a range of honeys, including manuka honey, coupled with their mechanism of action, is given in Table 2 .

There are phenolic compounds within manuka honey that remain unidentified. ${ }^{89}$ Some of these compounds, such as leptosperin, could have activity similar to MGO. ${ }^{91} \mathrm{~A}$ study testing 20 Canadian honeys showed that those containing the highest quantity of phenolic compounds, in this case wildflower and buckwheat honeys, also had the most antioxidant and antimicrobial activity. ${ }^{97}$ Other studies have also shown

Table 2 Brief description of the antibacterial compounds currently understood to be contained within honey and a description of their mechanism of action

\begin{tabular}{|c|c|c|c|}
\hline Component & Type of honey & Antimicrobial effect & References \\
\hline Bee defensin I & Revamil $^{\circledast}$ & $\begin{array}{l}\text { An antimicrobial peptide produced and secreted by the } \\
\text { bees into the honey. Bee defensin I has been isolated } \\
\text { from non-manuka honey. The antimicrobial activity } \\
\text { of bee defensin I is due to its ability to form pores } \\
\text { in bacterial membranes, compromising membrane } \\
\text { integrity and causing cell lysis. }\end{array}$ & 85,92 \\
\hline Hydrogen peroxide $\left(\mathrm{H}_{2} \mathrm{O}_{2}\right)$ & $\begin{array}{l}\text { Predominantly observed in } \\
\text { non-manuka honeys (although } \\
\text { low levels of activity are also } \\
\text { found in manuka honey) }\end{array}$ & $\begin{array}{l}\text { Generated by the activity of bee glucose oxidase, } \mathrm{H}_{2} \mathrm{O}_{2} \text { is } \\
\text { hypothesized to be a major antimicrobial component of } \\
\text { many non-manuka honeys. Although the concentration } \\
\text { of } \mathrm{H}_{2} \mathrm{O}_{2} \text { within honey is far below that used medically, it } \\
\text { is capable of causing DNA damage and interacting with } \\
\text { other components of the honey, increasing its activity } \\
\text { through hydroxyl radical production. }\end{array}$ & 31,50 \\
\hline Leptosperin & Manuka honey & $\begin{array}{l}\text { Initially named leptosin, this molecule is a novel glycoside } \\
\text { of methyl syringate, which inhibits myeloperoxidase } \\
\text { activity. Leptosperin is only found in manuka honey, and } \\
\text { so has been proposed as a biological marker for manuka } \\
\text { honey. Concentrations of leptosperin are positively } \\
\text { correlated with the antibacterial activity of manuka } \\
\text { honey, although to date, no mechanism of action has } \\
\text { been elucidated. }\end{array}$ & 93,91 \\
\hline Jelleins & $\begin{array}{l}\text { Canadian buckwheat honey, } \\
\text { and Canadian honey of a } \\
\text { mixed source also containing } \\
\text { buckwheat }\end{array}$ & $\begin{array}{l}\text { Antimicrobial peptides contained in the major royal } \\
\text { jelly precursor protein. Polypeptides with high affinity } \\
\text { to jelleins have been shown to cause cell membrane } \\
\text { damage in both Bacillus subtilis and Escherichia coli. }\end{array}$ & 94 \\
\hline Methylglyoxal (MGO) & Manuka honey & $\begin{array}{l}\text { MGO is found only in manuka honey, and concentrations } \\
\text { increase as honey ripens. During maturation, MGO is } \\
\text { converted from dihydroxyacetone via non-enzymatic } \\
\text { Maillard-like reactions. The antimicrobial activity of MGO } \\
\text { is derived from its ability to inactivate proteins by } \\
\text { cross-linking them. }\end{array}$ & $90,95,96$ \\
\hline
\end{tabular}


that in honey where $\mathrm{H}_{2} \mathrm{O}_{2}$ activity is not present (due to the addition of exogenous catalase), residual antioxidant activity is still observed. ${ }^{85,98}$

\section{The mechanism of action of methylglyoxal}

As mentioned above, manuka honey has been shown to have a very high level of non- $\mathrm{H}_{2} \mathrm{O}_{2}$ antimicrobial activity when compared to other honeys. This high level of activity has been measured and researched, and the improved levels of antibacterial efficacy have been attributed to several compounds isolated from manuka honey. ${ }^{85,87,99,100}$ The overall antibacterial activity of medical grade manuka honey is graded on one of two scales; MGO concentration within the honey, or unique manuka factor (UMF). The UMF rating is based on a linear relationship with phenol when tested against $S$. aureus. ${ }^{30}$ MGO is a 1,2-dicarbonyl compound, which is not exclusive to manuka honey, and can be widely found in foodstuffs. ${ }^{90,100}$ A study has demonstrated that MGO concentration within manuka honey is directly correlated to the UMF value, ${ }^{100}$ indicating that it is responsible for the antimicrobial activity observed. MGO concentrations are much higher in manuka honey (between 38 and $725 \mathrm{mg} / \mathrm{kg}$ ) than in other honey types (1.6 to $24 \mathrm{mg} / \mathrm{kg}) .{ }^{90}$

MGO can be formed both enzymatically and nonenzymatically, depending on the other components present in the honey and environmental conditions. ${ }^{101}$ MGO within manuka honey is primarily formed by the conversion of dihydroxyacetone to MGO by non-enzymatic Maillard reactions. ${ }^{96}$ Manuka honey collected from the hive often contains relatively low levels of MGO and a high concentration of dihydroxyacetone. During storage, this relationship inverts, and MGO levels within the honey increase, due to conversion of dihydroxyacetone. ${ }^{95}$

\section{Antibacterial properties of manuka honey}

Manuka honey is known to have antibacterial efficacy against a wide range pathogens, acting on both antibiotic-sensitive and antibiotic-resistant strains (Table 3).39,102,103

While MGO is deemed to produce the majority of manuka honey's antibacterial activity, it is interesting to note that its neutralization has negligible effects on manuka honey's ability to inhibit $P$. aeruginosa. This is in stark contrast to S. aureus and Bacillus subtilis, where the neutralization of MGO results in reduced activity. ${ }^{90,104}$ This result confirms the presence of other compounds with inhibitory efficacy, at least against $P$. aeruginosa. Due to the plethora of compounds within manuka honey, there will undoubtedly be a complex
Table 3 Species of bacteria known to be inhibited by manuka honey

\begin{tabular}{|c|c|c|}
\hline Achromobacter & Enterococcus & Pseudomonas \\
\hline xylosoxidans & faecium & aeruginosa \\
\hline Acinetobacter & Haemophilus & Salmonella spp. \\
\hline baumannii & influenzae & \\
\hline Burkholderia cepacia & Helicobacter pylori & Shigella spp. \\
\hline Burkholderia & Klebsiella & Stenotrophomonas \\
\hline cenocepacia & pneumoniae & maltophilia \\
\hline Campylobacter jejuni & $\begin{array}{l}\text { Listeria } \\
\text { monocytogenes }\end{array}$ & Streptococcus pyogenes \\
\hline Clostridium difficile & Neisseria spp. & Staphylococcus aureus \\
\hline Escherichia coli & Proteus spp. & Yersinia spp. \\
\hline
\end{tabular}

interplay between the various compounds. It is plausible that some interactions may lead to an additive/synergistic action not observed in the individual components. Therefore, the UMF rating appears to be the more thorough method of calculating antibacterial efficacy, encompassing "all" activity and not that derived solely from MGO; however, this theory does have limitations: only the activity against the organism tested can truly be confirmed, as some compounds appear to have organism-specific activity. Therefore, single organism testing (against $S$. aureus, in this instance) can lead to spurious results. Furthermore, as manuka honey contains a range of compounds, their diffusion through the agar may vary, producing misleading results. It is clear that manuka honey has antibacterial efficacy, but how we evaluate this activity should be further investigated. A standardized method (such as micro broth dilution) against a panel of organisms should ensure all aspects of inhibitory efficacy are captured in a reproducible way.

It is important to note that although manuka honey is the only honey currently recognized as having bioactive concentrations of MGO, studies have shown that it may be possible to augment non-manuka honeys by adding MGO or its precursor dihydroxyacetone. One study showed that the addition of dihydroxyacetone to clover honey led to MGO detection. ${ }^{95}$ In addition, supplementation of honeys with MGO can increase bactericidal activity to a level comparable with manuka honey. ${ }^{105}$ Similarly, supplementation with antimicrobial peptides, such as BP2, increased the speed of bacterial inactivation by Revamil ${ }^{\circledR}$ honey when used against in vitro cultures of six antibiotic-resistant bacterial species. ${ }^{104}$

To the best of our knowledge, bacterial resistance to manuka honey has not been observed in a clinical setting; however, the emergence of cells with decreased susceptibility to honey has been reported in vitro. ${ }^{106}$ However, the concentration of manuka honey tolerated was below that 
which would be achieved in clinical settings where undiluted manuka honey is used. Conversely, in studies investigating the purposeful passage of cells through sub-inhibitory concentrations of manuka honey did not result in a stable, resistant phenotype. ${ }^{82,103}$

Manuka honey has demonstrated efficacy against a range of organisms assuming the biofilm phenotype in vitro, ${ }^{56,60,107-109}$ has been shown to inhibit bacterial species where individual strains have vastly different biofilm-forming abilities, ${ }^{59}$ and has been proved to inhibit bacteria where multi-species biofilms are present. ${ }^{54} \mathrm{~A}$ study using manukatype honeys suggests $\mathrm{MGO}$ requires other components (excluding sugars) to have full antibiofilm actions. ${ }^{59}$ This result reinforces the notion that multiple compounds in manuka honey produce inhibitory effects, some of which might enhance others. When assessing MGO solely, it is capable of inhibiting $S$. aureus and $P$. aeruginosa biofilms, suggesting some role in the inhibition of this phenotype. ${ }^{109}$

While the antibacterial qualities of manuka honey alone are extremely promising, combination therapy is now being thoroughly scrutinized as a way of reinvigorating antibiotics that are no longer effective. ${ }^{110-112}$ Researchers have shown that in vitro combination therapy using sub-inhibitory concentrations of manuka honey reduces the Minimum Inhibitory Concentration (MIC) of antibiotics, effectively "reversing" AMR. ${ }^{39,80}$ To date, improved antibacterial efficacy for colistin, imipenem, mupirocin, rifampicin, and tetracycline has been demonstrated when combined with manuka honey. ${ }^{39,52}$ These additive/synergistic actions have also been observed against bacteria assuming a biofilm phenotype. ${ }^{55}$ Additive effects against $P$. aeruginosa biofilms treated with gentamicin and manuka honey and synergism between manuka honey and vancomycin against $S$. aureus biofilms have also been reported. ${ }^{55}$ These combinations open up a new avenue for future antimicrobial development. Furthermore, with inhibitory activity demonstrated against biofilms, ${ }^{9}$ the potential for manuka honey to be utilized clinically, inhibiting both acute and chronic infections, is highly promising.

\section{Mechanisms of antibacterial action of manuka honey}

The mechanism of action for manuka honey's antibacterial activity has mainly been elucidated against two prominent opportunistic pathogens: $S$. aureus and P. aeruginosa. Interestingly, these mechanistic activities appear to differ greatly from one another. The first documented mechanistic activity for manuka honey was observed against $S$. aureus, where marked structural changes were observed in S. aureus cells treated with inhibitory concentrations. ${ }^{113}$

It was later confirmed that manuka honey causes disruption to the regular cell division process of $S$. aureus ${ }^{114}$ (Figure 1). Under optimal conditions, bacterial cells duplicate and segregate their chromosome, forming a proteinaceous ring (the septum) across the midcell, creating two still-joined daughter cells. ${ }^{115}$ The completion of cell division occurs when peptidoglycan (murein) hydrolases degrade the cell wall between the two daughter cells, allowing separation. ${ }^{116}$ Manuka honey has been shown to inhibit the activity (and not the

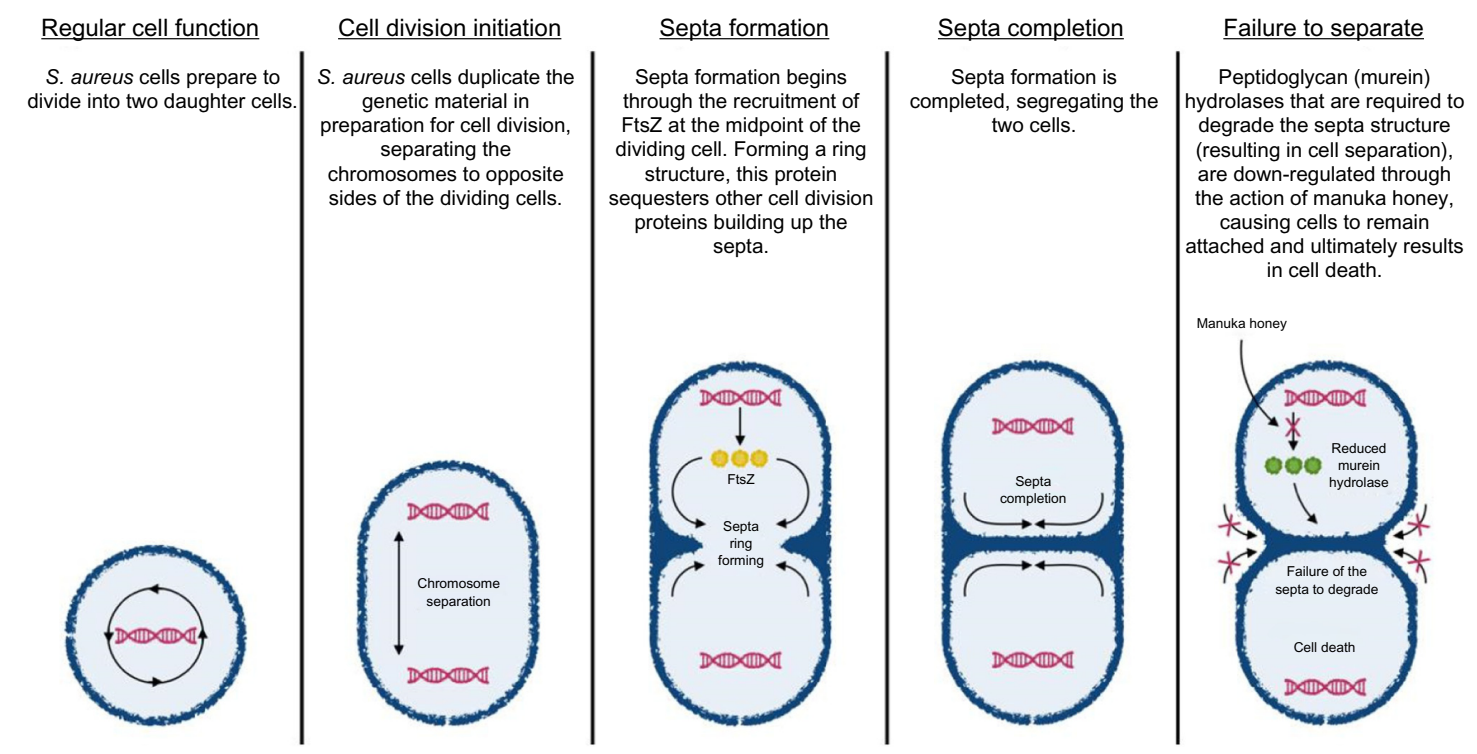

Figure I The proposed mechanism by which manuka honey inhibits methicillin-resistant Staphylococcus aureus (MRSA). Manuka honey is thought to affect the latter stages of cell division, following the completion of the septa formation. The reduced production of murein (peptidoglycan) hydrolase and/or its sequestering into an inactive state results in the two daughter cells remaining attached due to the inability of the septa to be degraded, which ultimately leads to cell death. 
expression) of murein hydrolase, causing a build-up of septated non-dividing cells. ${ }^{114}$ Interestingly, many papers conclude the antibacterial action of manuka honey against $S$. aureus is bactericidal; ${ }^{85,104,113}$ however, the mechanism described points more toward bacteriostatic activity. Potentially, cells may be viable yet non-culturable. Several papers conclude that the effects seen are independent of the sugars within honey, ${ }^{113}$ with one suggesting MGO is also not the causative agent of these inhibitory effects. ${ }^{114}$

In contrast to the mechanism observed in S. aureus, studies have proposed an entirely different mechanism against P. aeruginosa. . aeruginosa cells can tolerate higher concentrations of manuka honey when compared to S. aureus, with inhibitory concentrations causing the loss of cellular integrity, leading to extensive cell lysis and cell death. ${ }^{117}$ $P$. aeruginosa modulates its structural integrity through the production of a key anchor protein: outer membrane protein $\mathrm{F}$ (OprF). ${ }^{118}$ This protein provides a vital link between the outer membrane and underlying peptidoglycan layer, ensuring cell envelope homeostasis and regular cell shape. ${ }^{118,119}$ Reduced OprF expression has been observed in populations treated with manuka honey, and a concomitant increase in membrane blebbing and cell lysis has also been detected (Figure 2). ${ }^{120}$

The different mechanistic actions observed against $P$. aeruginosa (compared to $S$. aureus) highlights the potential for multiple modes of action, and multiple inhibitory compounds in manuka honey. One noteworthy point is that the conserved nature of the cell division process among bacteria suggests manuka honey may affect the cell division process of $P$. aeruginosa. This effect was not observed in the studies above; however, the rate at which cell lysis occurs may not allow for such observations. Published work highlights the necessity of membrane potential for the correct spatial organization of cell division proteins and regular cell division function. ${ }^{121}$ This indicates an as yet unidentified link between the mechanistic effects observed in $S$. aureus and $P$. aeruginosa.

In other studies, exposure to manuka honey has been shown to have other effects against a range of organisms. Against $P$. aeruginosa, manuka honey suppresses the class I master regulators (Fle $Q$ and FliA), inhibiting the regulatory cascade required for flagellum production and leading to a significant reduction in flagellated cells. ${ }^{61}$ This observation is of clinical significance as adhesion and cellular motility are required for invasive virulence. ${ }^{122,123}$ Invasive virulence is problematic, as it allows the dissemination of cells through the bloodstream (bacteremia) to internal organs, which can prove fatal; therefore, the potential to reduce this process is highly valuable. The ability of $P$. aeruginosa to sequester iron from a host may also be prohibited through manuka honey treatment, following the observation of reduced siderophore production in treated samples. ${ }^{124}$ Sub-inhibitory concentrations are shown to inhibit cellular binding with fibronectin through the loss of two streptococcal surface proteins, SoF and SfbI. ${ }^{107}$ In wound infections, high concentrations of fibronectin are observed; ${ }^{125}$ therefore,

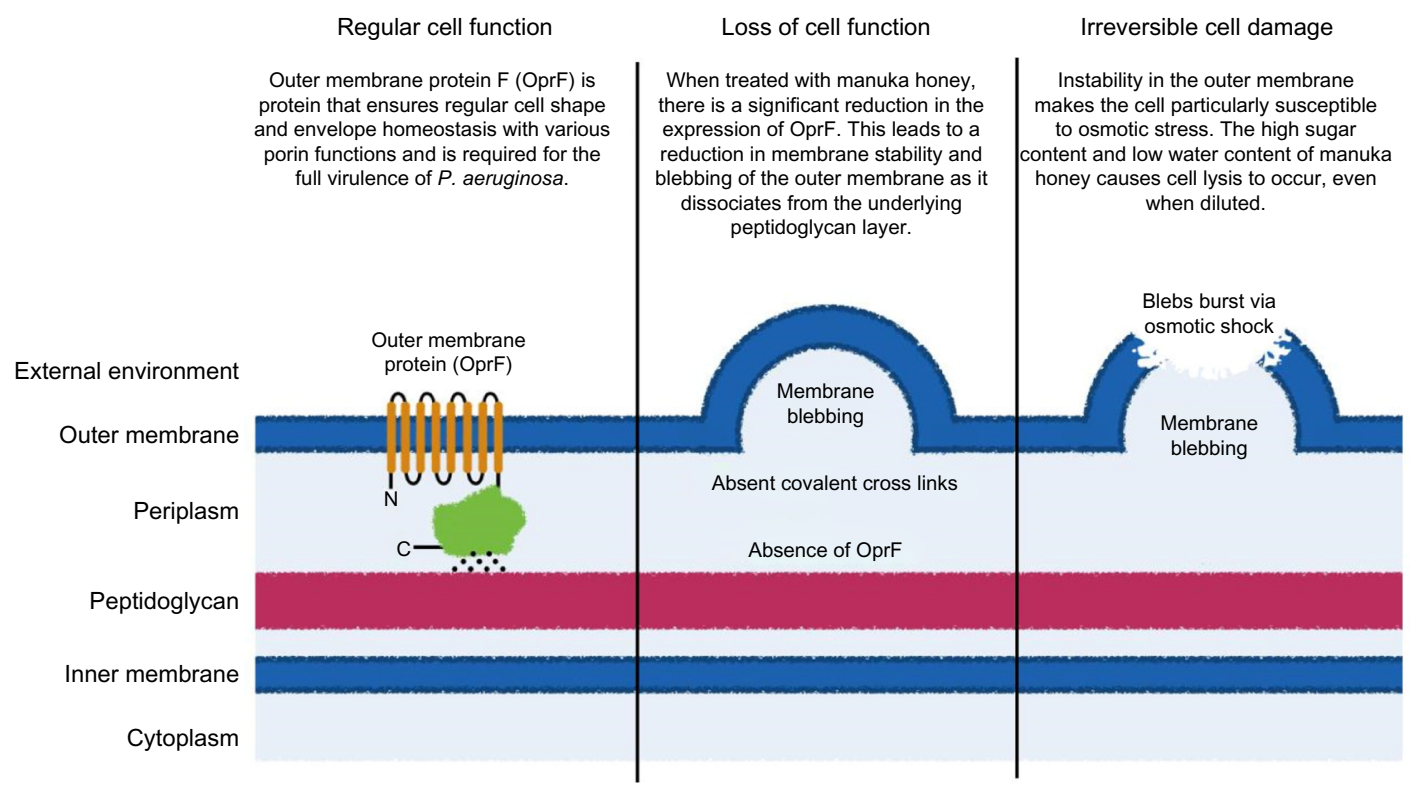

Figure 2 The proposed mechanism by which manuka honey inhibits Pseudomonas aeruginosa. Manuka honey is proposed to cause destabilization of the cell envelope through the down-regulation of a key structural protein (OprF), which is involved in maintaining cell shape and cell envelope stability. The loss of this protein results in membrane blebbing, which decreases cellular viability and ultimately leads to cell lysis. 
the inability of Streptococcus pyogenes to bind to the host may impact on its pathogenicity.

In addition to the studies into $S$. aureus, P. aeruginosa, and $S$. pyogenes, a study into the global action of manuka honey on Escherichia coli demonstrated that following exposure to manuka honey, $2 \%$ of the genes were up-regulated, while $1 \%$ were down-regulated by twofold or more. ${ }^{103}$ Up-regulation appears to occur across genes involved in stress response; those genes down-regulated are thought to encode products involved in protein synthesis. ${ }^{103}$ Conversely, down-regulation (16-fold) of a universal stress protein A (UspA) in S. aureus cells treated with honey was observed. ${ }^{126}$ Another study has shown large-scale down-regulation of critical virulence genes (enterotoxins, fibronectin-binding proteins, hemolysins, and lipases), with concomitant reductions in global regulators and quorum-sensing genes. ${ }^{51}$ These mechanistic effects, both lethal and non-lethal, are a testament to the inhibitory efficacy of manuka honey and confirm its broad spectrum of effects.

\section{Applications of manuka honey as an antibacterial agent}

Given the remarkable properties of manuka honey, it is unsurprising that there are now several licensed medical products based on manuka honey available, and it is worth noting that in addition to antimicrobial compounds, honey also contains compounds that enable it to modulate the activity of immune cells and promote rapid wound healing. ${ }^{46,65,67}$ However, despite the claims made, its use has mainly been restricted to use as an antibacterial agent in the treatment of infected burns and wounds. ${ }^{78,79}$

This limited uptake of honey in clinical practice could in part be due to a lack of high-quality evidence supporting its use clinically. Despite the large amount of in vitro work supporting its potential in vivo use, systematic reviews covering the use of honey in wound management have mostly stated that the evidence for clinical use is weak. However, when considering end-point measurements chosen (healing rather than antibacterial activity), inconsistent study design, varying honeys used, and diverse patient population, it is easy to see why it has been difficult to satisfactorily collate the data. ${ }^{48,127-131} \mathrm{~A}$ recent systematic review has given a positive view on the evidence supporting honey, suggesting that honey does lead to improved healing in a variety of wounds, including partial thickness burns, as well as acute and chronic wounds, when compared to silver sulfadiazine or sugar dressings. ${ }^{128}$ There is clearly still a need for larger scale, well-designed multicenter randomized clinical trials to improve the evidence base available.

\section{Conclusion}

AMR is one of the greatest medical challenges the world faces; it was estimated recently that by 2050 , AMR will account for ten million extra deaths annually worldwide, with additional economic costs in the region of $\$ 100$ trillion. $^{132}$ In order to combat this challenge, antimicrobial agents with a broad spectrum of activity are required. There is potential to use honey to target virulence rather than viability, thereby reducing the likelihood of resistance occurring and making it an interesting candidate for further investigation.

The ability of manuka to act synergistically with antibiotics also opens up new possibilities for its use as a topical agent and possibly as part of a combined regimen. Such statements do raise immediate problems, however; one of the largest hurdles facing manuka honey's introduction as a front-line product (and not last-resort, as is often the case) is the ability to reproduce the excellent efficacy observed in vitro during in vivo clinical trials. Additionally, the integration of manuka honey into mainstream wound care would ideally require the exact composition of honey to be fully investigated. This would allow assessment of the complex interplay compounds may have with one another, and may help clinicians determine whether honeys (manuka or otherwise) would be more effective against certain infection-causing species. Until the exact compounds causing inhibitory effects are identified and their interplay with other compounds investigated, the uptake of manuka honey in the clinical environment will remain inconsistent, possibly to the detriment of patients.

\section{Disclosure}

The authors report no conflict of interest in this work.

\section{References}

1. Pantosti A, Venditti M. What is MRSA? Eur Respir J. 2009;34(5): 1190-1196.

2. Chen CH, Lin LC, Chang YJ, Chen YM, Chang CY, Huang CC. Infection control programs and antibiotic control programs to limit transmission of multi-drug resistant Acinetobacter baumannii infections: evolution of old problems and new challenges for institutes. Int J Environ Res Public Health. 2015;12(8):8871-8882.

3. Daniel DS, Lee SM, Dykes GA, Rahman S. Public health risks of multipledrug-resistant Enterococcus spp. in Southeast Asia. 2015;81(18): 6090-6097.

4. Høiby N, Bjarnsholt T, Givskov M, Molin S, Ciofu O. Antibiotic resistance of bacterial biofilms. Int J Antimicrob Agents. 2010;35(4):322-332.

5. Karlowsky JA, Kelly LJ, Thornsberry C, Jones ME, Sahm DF. Trends in antimicrobial resistance among urinary tract infection isolates of Escherichia coli from female outpatients in the United States. Antimicrob Agents Chemother. 2002;46(8):2540-2545.

6. Thornton RB, Wiertsema SP, Kirkham LA, et al. Neutrophil extracellular traps and bacterial biofilms in middle ear effusion of children with recurrent acute otitis media - a potential treatment target. PLoS One. 2013;8(2):e53837. 
7. Thornton RB, Rigby PJ, Wiertsema SP, et al. Multi-species bacterial biofilm and intracellular infection in otitis media. BMC Pediatr. 2011;11:94.

8. Anvarinejad M, Japoni A, Rafaatpour N, et al. Burn patients infected with metallo-beta-lactamase-producing Pseudomonas aeruginosa: multidrug-resistant strains. Arch Trauma Res. 2014;3(2):e18182.

9. Philips PL. Yang QDS, Sampson EM, Azeke A, Schultz GS. Antimicrobial dressing efficacy against mature Pseudomonas aeruginosa biofilm on procine skin explants. Int Wound J. 2015;12(4):469-483.

10. Huttner A, Harbarth S, Carlet J, et al. Antimicrobial resistance: a global view from the 2013 World Healthcare-Associated Infections Forum. Antimicrob Resist Infect Control. 2013;2:31.

11. Fischbach MA, Walsh CT. Antibiotics for emerging pathogens. Science. August 28, 2009;325(5944):1089-1093.

12. Bragginton EC, Piddock LJ. UK and European Union public and charitable funding from 2008 to 2013 for bacteriology and antibiotic research in the UK: an observational study. Lancet Infect Dis. 2014;14(9): $857-868$.

13. Römling U, Kjelleberg S, Normark S, Nyman L, Uhlin BE, Åkerlund B. Microbial biofilm formation: a need to act. J Intern Med. 2014;276(2): 98-110.

14. Roberts RR, Hota B, Ahmad I, et al. Hospital and societal costs of antimicrobial-resistant infections in a Chicago teaching hospital: implications for antibiotic stewardship. Clin Infect Dis. 2009;49(8):1175-1184.

15. Smith R, Coast J. The true cost of antimicrobial resistance. BMJ. 2013;346:f1493.

16. Allen HK, Trachsel J, Looft T, Casey TA. Finding alternatives to antibiotics. Ann N Y Acad Sci. 2014;1323(1):91-100.

17. Prabhu S, Poulose E. Silver nanoparticles: mechanism of antimicrobial action, synthesis, medical applications, and toxicity effects. Int Nano Lett. 2012;2(1):1-10.

18. Hyldgaard M, Mygind T, Meyer RL. Essential oils in food preservation: mode of action, synergies, and interactions with food matrix components. Front Microbiol. 2012;3:12.

19. Viuda-Martos M, Ruiz-Navajas Y, Fernández-López J, Pérez-Álvarez JA. Functional properties of honey, propolis, and royal jelly. J Food Sci. 2008;73(9):R117-R124.

20. Sulakvelidze A, Alavidze Z, Morris JG Jr. Bacteriophage therapy. Antimicrob Agents Chemother. 2001;45(3):649-659.

21. Dizaj SM, Lotfipour F, Barzegar-Jalali M, Zarrintan MH, Adibkia K. Antimicrobial activity of the metals and metal oxide nanoparticles. Mater Sci Eng C Mater Biol Appl. 2014;44:278-284.

22. Hraiech S, Brégeon F, Rolain JM. Bacteriophage-based therapy in cystic fibrosis-associated Pseudomonas aeruginosa infections: rationale and current status. Drug Des Devel Ther. 2015;9:3653-3663.

23. Maddocks SE, Jenkins RE, Rowlands RS, Purdy KJ, Cooper RA. Manuka honey inhibits adhesion and invasion of medically important wound bacteria in vitro. Future Microbiol. 2013;8(12):1523-1536.

24. Merckoll P, Jonassen TØ, Vad ME, Jeansson SL, Melby KK. Bacteria, biofilm and honey: a study of the effects of honey on 'planktonic' and biofilm-embedded chronic wound bacteria. Scand J Infect Dis. 2009;41(5):341-347.

25. Alvarez-Suarez J, Tulipani S, Romandini S, Bertoli E, Battino M. Contribution of honey in nutrition and human health: a review. Med J Nutrition Metab. 2010;3(1):15-23.

26. Ruiz-Argueso T, Rodriguez-Navarro A. Microbiology of ripening honey. Appl Microbiol. 1975;30(6):893-896.

27. Eteraf-Oskouei T, Najafi M. Traditional and modern uses of natural honey in human diseases: a review. Iran J Basic Med Sci. 2013;16(6): 731-742.

28. Alvarez-Suarez JM, Giampieri F, Battino M. Honey as a source of dietary antioxidants: structures, bioavailability and evidence of protective effects against human chronic diseases. Curr Med Chem. 2013;20(5):621-638.

29. Alvarez-Suarez JM, Gasparrini M, Forbes-Hernández TY, Mazzoni L, Giampieri F. The composition and biological activity of honey: a focus on manuka honey. Foods. 2014;3(3):420-432.
30. Allen KL, Molan PC, Reid GM. A survey of the antibacterial activity of some New Zealand honeys. J Pharm Pharmacol. 1991;43(12): 817-822.

31. Brudzynski K, Abubaker K, St-Martin L, Castle A. Re-examining the role of hydrogen peroxide in bacteriostatic and bactericidal activities of honey. Front Microbiol. 2011;2:213.

32. Tonks AJ, Cooper RA, Jones KP, Blair S, Parton J, Tonks A. Honey stimulates inflammatory cytokine production from monocytes. Cytokine. 2003;21(5):242-247.

33. Erejuwa OO, Sulaiman SA, Wahab MS, Sirajudeen KN, Salleh MS, Gurtu S. Glibenclamide or metformin combined with honey improves glycemic control in streptozotocin-induced diabetic rats. Int J Biol Sci. 2011;7(2):244-252.

34. Al-Waili NS. Natural honey lowers plasma glucose, C-reactive protein, homocysteine, and blood lipids in healthy, diabetic, and hyperlipidemic subjects: comparison with dextrose and sucrose. JMed Food. 2004;7(1): 100-107.

35. Fernandez-Cabezudo MJ, El-Kharrag R, Torab F, et al. Intravenous Administration of Manuka Honey Inhibits Tumor Growth and Improves Host Survival When Used in Combination with Chemotherapy in a Melanoma Mouse Model. PLoS One. 2013;8(2):e55993.

36. Irish J, Carter DA, Shokohi T, Blair SE. Honey has an antifungal effect against Candida species. Med Mycol. 2006;44(3):289-291.

37. Watanabe K, Rahmasari R, Matsunaga A, Haruyama T, Kobayashi N. Anti-influenza viral effects of honey in vitro: potent high activity of manuka honey. Arch Med Res. 2014;45(5):359-365.

38. Cooper R, Jenkins L, Hooper S. Inhibition of biofilms of Pseudomonas aeruginosa by Medihoney in vitro. J Wound Care. 2014;23(3):93-96, 98-100, 102 passim.

39. Jenkins R, Cooper R. Improving antibiotic activity against wound pathogens with manuka honey in vitro. PLoS One. 2012;7(9):e45600.

40. Maddocks SE, Jenkins RE. Honey: a sweet solution to the growing problem of antimicrobial resistance? Future Microbiol. 2013;8(11):1419-1429.

41. Zumla A, Lulat A. Honey - a remedy rediscovered. J R Soc Med. 1989; 82(7):384-385.

42. Cooper R. The modern use of honey in the treatment of wounds. Bee World. 2005;86(4):110-113.

43. Salehi A, Jabarzare S, Neurmohamadi M, Kheiri S, Rafieian-Kopaei M. A double blind clinical trial on the efficacy of honey drop in vernal keratoconjunctivitis. Evid Based Complement Alternat Med. 2014;2014: 287540.

44. Al-Waili NS. Investigating the antimicrobial activity of natural honey and its effects on the pathogenic bacterial infections of surgical wounds and conjunctiva. J Med Food. 2004;7(2):210-222.

45. Chang EH, Alandejani T, Akbari E, Ostry A, Javer A. Double-blinded, randomized, controlled trial of medicated versus nonmedicated merocel sponges for functional endoscopic sinus surgery. J Otolaryngol Head Neck Surg. 2011;40(Suppl 1):S14-S19.

46. Efem SE. Clinical observations on the wound healing properties of honey. Br J Surg. 1988;75(7):679-681.

47. Molan PC. The evidence supporting the use of honey as a wound dressing. Int J Low Extrem Wounds. 2006;5(1):40-54.

48. Moore OA, Smith LA, Campbell F, Seers K, McQuay HJ, Moore RA. Systematic review of the use of honey as a wound dressing. $B M C$ Complement Altern Med. 2001;1:2.

49. Phillips PL, Yang Q, Davis S, et al. Antimicrobial dressing efficacy against mature Pseudomonas aeruginosa biofilm on porcine skin explants. Int Wound J. 2015;12(4):469-483.

50. Brudzynski K, Lannigan R. Mechanism of honey bacteriostatic action against MRSA and VRE involves hydroxyl radicals generated from honey's hydrogen peroxide. Front Microbiol. 2012;3:36.

51. Jenkins R, Burton N, Cooper R. Proteomic and genomic analysis of methicillin-resistant Staphylococcus aureus (MRSA) exposed to manuka honey in vitro demonstrated down-regulation of virulence markers. J Antimicrob Chemother. 2014;69(3):603-615.

52. Müller P, Alber DG, Turnbull L, et al. Synergism between Medihoney and rifampicin against methicillin-resistant Staphylococcus aureus (MRSA). PLoS One. 2013;8(2):e57679. 
53. Ansari MJ, Al-Ghamdi A, Usmani S, et al. Effect of jujube honey on Candida albicans growth and biofilm formation. Arch Med Res. 2013;44(5):352-360.

54. Badet C, Quero F. The in vitro effect of manuka honeys on growth and adherence of oral bacteria. Anaerobe. 2011;17(1):19-22.

55. Campeau ME, Patel R. Antibiofilm activity of Manuka honey in combination with antibiotics. Int J Bacteriol. 2014;2014:1-7.

56. Hammond EN, Donkor ES, Brown CA. Biofilm formation of Clostridium difficile and susceptibility to Manuka honey. BMC Complement Altern Med. 2014;14:329.

57. Lee JH, Park JH, Kim JA, et al. Low concentrations of honey reduce biofilm formation, quorum sensing, and virulence in Escherichia coli O157:H7. Biofouling. 2011;27(10):1095-1104.

58. Lerrer B, Zinger-Yosovich KD, Avrahami B, Gilboa-Garber N. Honey and royal jelly, like human milk, abrogate lectin-dependent infection-preceding Pseudomonas aeruginosa adhesion. ISME J. 2007;1(2):149-155.

59. Lu J, Turnbull L, Burke CM, et al. Manuka-type honeys can eradicate biofilms produced by Staphylococcus aureus strains with different biofilm-forming abilities. PeerJ. 2014;2:e326.

60. Majtan J, Bohova J, Horniackova M, Klaudiny J, Majtan V. Anti-biofilm effects of honey against wound pathogens Proteus mirabilis and Enterobacter cloacae. Phytother Res. 2014;28(1):69-75.

61. Roberts AE, Maddocks SE, Cooper RA. Manuka honey reduces the motility of Pseudomonas aeruginosa by suppression of flagellaassociated genes. J Antimicrob Chemother. 2015;70(3):716-725.

62. Matongo F, Nwodo UU. In vitro assessment of Helicobacter pylori ureases inhibition by honey fractions. Arch Med Res. 2014;45(7) 540-546.

63. Manyi-Loh CE, Clarke AM, Munzhelele T, Green E, Mkwetshana NF, Ndip RN. Selected South African honeys and their extracts possess in vitro anti-Helicobacter pylori activity. Arch Med Res. 2010;41(5):324-331

64. Witman CE, Downs BW. Topical honey for scalp defects: an alternative to surgical scalp reconstruction. Plast Reconstr Surg Glob Open. 2015;3(5):e393.

65. Ker-Woon C, Abd Ghafar N, Hui CK, Mohd Yusof YA, Wan Ngah WZ. The effects of acacia honey on in vitro corneal abrasion wound healing model. BMC Cell Biol. 2015;16:2

66. Mohamed H, Salma MA, Al Lenjawi B, et al. The efficacy and safety of natural honey on the healing of foot ulcers: a case series. Wounds. 2015;27(4):103-114.

67. Gray C, Ishii F. Using active Leptospermum honey in the debridement process: 6 challenging cases from the inner city. Ostomy Wound Manage. 2015;61(4):63-66.

68. Amaya R. Safety and efficacy of active Leptospermum honey in neonatal and paediatric wound debridement. $J$ Wound Care. 2015;24(3):95;97-103.

69. Haffejee IE, Moosa A. Honey in the treatment of infantile gastroenteritis. Br Med J (Clin Res Ed). 1985;290(6485):1866-1867.

70. Abdulrhman MA, Mekawy MA, Awadalla MM, Mohamed AH. Bee honey added to the oral rehydration solution in treatment of gastroenteritis in infants and children. J Med Food. 2010;13(3): 605-609.

71. Sadeghi-Aliabadi H, Hamzeh J, Mirian M. Investigation of Astragalus honey and propolis extract's cytotoxic effect on two human cancer cell lines and their oncogen and proapoptotic gene expression profiles. $A d v$ Biomed Res. 2015;4:42.

72. Cho HK, Jeong YM, Lee HS, Lee YJ, Hwang SH. Effects of honey on oral mucositis in patients with head and neck cancer: a meta-analysis. Laryngoscope. 2015;125(9):2085-2092.

73. Munstedt K, Voss B, Kullmer U, Schneider U, Hübner J. Bee pollen and honey for the alleviation of hot flushes and other menopausal symptoms in breast cancer patients. Mol Clin Oncol. 2015;3(4):869-874.

74. Hamad R, Jayakumar C, Ranganathan P, et al. Honey feeding protects kidney against cisplatin nephrotoxicity through suppression of inflammation. Clin Exp Pharmacol Physiol. 2015;42(8):843-848
75. Kamaruzaman NA, Sulaiman SA, Kaur G, Yahaya B. Inhalation of honey reduces airway inflammation and histopathological changes in a rabbit model of ovalbumin-induced chronic asthma. BMC Complement Altern Med. 2014;14:176.

76. Borsato DM, Prudente AS, Döll-Boscardin PM, et al. Topical antiinflammatory activity of a monofloral honey of Mimosa scabrella provided by Melipona marginata during winter in southern Brazil. J Med Food. 2014;17(7):817-825.

77. Octoratou M, Merikas E, Malgarinos G, Stanciu C, Triantafillidis JK. A prospective study of pre-illness diet in newly diagnosed patients with Crohn's disease. Rev Med Chir Soc Med Nat lasi. 2012;116(1):40-49.

78. Kwakman PHS, Van den Akker JPC, Güçlü A, et al. Medical-grade honey kills antibiotic-resistant bacteria in vitro and eradicates skin colonization. Clin Infect Dis. 2008;46(11):1677-1682.

79. Visavadia BG, Honeysett J, Danford MH. Manuka honey dressing: an effective treatment for chronic wound infections. Br J Oral Maxillofac Surg. 2008;46(1):55-56.

80. Jenkins RE, Cooper R. Synergy between oxacillin and manuka honey sensitizes methicillin-resistant Staphylococcus aureus to oxacillin. Journal of Antimicrobial Chemotherapy. 2012;67(6):1405-1407.

81. Medhi B, Prakash A, Avti PK, Saikia UN, Pandhi P, Khanduja KL. Effect of manuka honey and sulfasalazine in combination to promote antioxidant defense system in experimentally induced ulcerative colitis model in rats. Indian J Exp Biol. 2008;46(8):583-590.

82. Cooper RA, Jenkins L, Henriques AF, Duggan RS, Burton NF. Absence of bacterial resistance to medical-grade manuka honey. Eur J Clin Microbiol Infect Dis. 2010;29(10):1237-1241.

83. Cooper R, Jenkins R. Are there feasible prospects for manuka honey as an alternative to conventional antimicrobials? Expert Rev Anti Infect Ther. 2012;10(6):623-625.

84. Bang LM Buntting C, Molan P. The effect of dilution on the rate of hydrogen peroxide production in honey and its implications for wound healing. J Altern Complement Med. 2004;9(2):267-273.

85. Kwakman PH, te Velde AA, de Boer L, Speijer D, VandenbrouckeGrauls CM, Zaat SA. How honey kills bacteria. FASEB J. 2010;24(7): 2576-2582.

86. Daher S, Gülaçar FO. Identification of new aromatic compounds in the New Zealand manuka honey by gas chromatography-mass spectrometry. J Chem. 2010;7(S1):S7-S14.

87. Weston RJ, Mitchell KR, Allen KL. Antibacterial phenolic components of New Zealand manuka honey. Food Chem. 1999;64(3):295-301.

88. Blasa M, Candiracci M, Accorsi A, Piacentini MP, Piatti E. Honey flavonoids as protection agents against oxidative damage to human red blood cells. Food Chem. 2007;104(4):1635-1640.

89. Oelschlaegel S, Gruner M, Wang PN, Boettcher A, Koelling-Speer I, Speer K. Classification and Characterization of Manuka Honeys Based on Phenolic Compounds and Methylglyoxal. J Agric Food Chem. 2012;60(29):7229-7237.

90. Adams CJ, Boult CH, Deadman BJ, et al. Isolation by HPLC and characterisation of the bioactive fraction of New Zealand manuka (Leptospermum scoparium) honey. Carbohydr Res. 2008;343(4):651-659.

91. Kato Y, Fujinaka R, Ishisaka A, Nitta Y, Kitamoto N, Takimoto Y. Plausible authentication of manuka honey and related products by measuring leptosperin with methyl syringate. J Agric Food Chem. 2014;62(27):6400-6407.

92. Klaudiny J, Albert S, Bachanová K, Kopernický J, Simúth J. Two structurally different defensin genes, one of them encoding a novel defensin isoform, are expressed in honeybee Apis mellifera. Insect Biochem Mol Biol. 2005;35(1):11-22.

93. Kato Y, Umeda N, Maeda A, Matsumoto D, Kitamoto N, Kikuzaki H Identification of a novel glycoside, leptosin, as a chemical marker of manuka honey. J Agric Food Chem. 2012;60(13):3418-3423.

94. Brudzynski K, Sjaarda C. Honey glycoproteins containing antimicrobial peptides, jelleins of the major royal jelly protein 1 , are responsible for the cell wall lytic and bactericidal activities of honey. PLoS One. 2015;10(4):e0120238. 
95. Adams CJ, Manley-Harris M, Molan PC. The origin of methylglyoxal in New Zealand manuka (Leptospermum scoparium) honey. Carbohydrate Res. 2009;344(8):1050-1053.

96. Weigel KU, Opitz T, Henle T. Studies on the occurrence and formation of 1,2-dicarbonyls in honey. Eur Food Res Technol. 2004;218(2):147-151.

97. Brudzynski K, Miotto D. The relationship between the content of Maillard reaction-like products and bioactivity of Canadian honeys. Food Chem. 2011;124(3):869-874.

98. Irish J, Blair S, Carter DA. The antibacterial activity of honey derived from Australian flora. PLoS One. 2011;6(3):e18229.

99. Lu J, Carter DA, Turnbull L, et al. The effect of New Zealand kanuka, manuka and clover honeys on bacterial growth dynamics and cellular morphology varies according to the species. PLoS One. 2013;8(2):e55898.

100. Mavric E, Wittmann S, Barth G, Henle T. Identification and quantification of methylglyoxal as the dominant antibacterial constituent of Manuka (Leptospermum scoparium) honeys from New Zealand. Mol Nutr Food Res. 2008;52(4):483-489.

101. Nemet I, Varga-Defterdarović L, Turk Z. Methylglyoxal in food and living organisms. Mol Nutr Food Res. 2006;50(12):1105-1117.

102. Cooper RA, Molan PC, Harding KG. The sensitivity to honey of Gram-positive cocci of clinical significance isolated from wounds. $J$ Appl Microbiol. 2002;93(5):857-863.

103. Blair SE, Cokcetin NN, Harry EJ, Carter DA. The unusual antibacterial activity of medical-grade Leptospermum honey: antibacterial spectrum, resistance and transcriptome analysis. Eur J Clin Microbiol Infect Dis. 2009;28(10):1199-1208.

104. Kwakman PH, de Boer L, Ruyter-Spira CP, et al. Medical-grade honey enriched with antimicrobial peptides has enhanced activity against antibiotic-resistant pathogens. Eur J Clin Microbiol Infect Dis. 2011;30(2):251-257.

105. Jervis-Bardy J, Foreman A, Bray S, Tan L, Wormald PJ. Methylglyoxalinfused honey mimics the anti-Staphylococcus aureus biofilm activity of manuka honey: potential implication in chronic rhinosinusitis. Laryngoscope. 2011;121(5):1104-1107.

106. Camplin AL, Maddocks SE. Manuka honey treatment of biofilms of Pseudomonas aeruginosa results in the emergence of isolates with increased honey resistance. Ann Clin Microbiol Antimicrob. 2014;13:19.

107. Maddocks SE, Lopez MS, Rowlands RS, Cooper RA. Manuka honey inhibits the development of Streptococcus pyogenes biofilms and causes reduced expression of two fibronectin binding proteins. Microbiology. 2012;158(Pt 3):781-790.

108. Alandejani T, Marsan J, Ferris W, Slinger R, Chan F. Effectiveness of honey on Staphylococcus aureus and Pseudomonas aeruginosa biofilms. Otolaryngol Head Neck Surg. Jul 2009;141(1):114-118.

109. Kilty SJ, Duval M, Chan FT, Ferris W, Slinger R. Methylglyoxal: (active agent of manuka honey) in vitro activity against bacterial biofilms. Int Forum Allergy Rhinol. 2011;1(5):348-350.

110. Fischbach MA. Combination therapies for combating antimicrobial resistance. Curr Opin Microbiol. 2011;14(5):519-523.

111. Rahal JJ. Novel antibiotic combinations against infections with almost completely resistant Pseudomonas aeruginosa and Acinetobacter species. Clin Infect Dis. 2006;43(Suppl 2):S95-S99.

112. Tamma PD, Cosgrove SE, Maragakis LL. Combination therapy for treatment of infections with gram-negative bacteria. Clin Microbiol Rev. 2012;25(3):450-470.

Research and Reports in Biology

\section{Publish your work in this journal}

Research and Reports in Biology is an international, peer-reviewed, open access journal publishing original research, reports, editorials, reviews and commentaries on all areas of biology including animal biology, biochemical biology, cell biology, ecological studies, evolutionary biology, molecular biology, plant science and botany. The
113. Henriques AF, Jenkins RE, Burton NF, Cooper RA. The intracellular effects of manuka honey on Staphylococcus aureus. Eur J Clin Microbiol Infect Dis. 2010;29(1):45-50.

114. Jenkins R, Burton N, Cooper R. Manuka honey inhibits cell division in methicillin-resistant Staphylococcus aureus. JAntimicrob Chemother. 2011;66(11):2536-2542.

115. Amick JD, Brun YV. Anatomy of a bacterial cell cycle. Genome Biol. 2001;2(7):REVIEWS1020.

116. Priyadarshini R, de Pedro MA, Young KD. Role of peptidoglycan amidases in the development and morphology of the division septum in Escherichia coli. J Bacteriol. 2007;189(14):5334-5347.

117. Henriques AF, Jenkins RE, Burton NF, Cooper RA. The effect of manuka honey on the structure of Pseudomonas aeruginosa. Eur $J$ Clin Microbiol Infect Dis. Feb 2011;30(2):167-171.

118. Gotoh N, Wakebe H, Yoshihara E, Nakae T, Nishino T. Role of protein $\mathrm{F}$ in maintaining structural integrity of the Pseudomonas aeruginosa outer membrane. J Bacteriol. 1989;171(2):983-990.

119. Sugawara E, Steiert M, Rouhani S, Nikaido H. Secondary structure of the outer membrane proteins OmpA of Escherichia coli and OprF of Pseudomonas aeruginosa. J Bacteriol. 1996;178(20):6067-6069.

120. Roberts AE, Maddocks SE, Cooper RA. Manuka honey is bactericidal against Pseudomonas aeruginosa and results in differential expression of oprF and algD. Microbiology. 2012;158(Pt 12):3005-3013.

121. Strahl H, Hamoen LW. Membrane potential is important for bacterial cell division. Proc Natl Acad Sci U SA. 2010;107(27):12281-12286.

122. Drake D, Montie TC. Flagella, motility and invasive virulence of Pseudomonas aeruginosa. J Gen Microbiol. 1988;134(1):43-52.

123. Haiko J, Westerlund-Wikström B. The role of the bacterial flagellum in adhesion and virulence. Biology (Basel). 2013;2(4):1242-1267.

124. Kronda JM, Cooper RA, Maddocks SE. Manuka honey inhibits siderophore production in Pseudomonas aeruginosa. JAppl Microbiol. 2013;115(1):86-90.

125. To WS, Midwood KS. Plasma and cellular fibronectin: distinct and independent functions during tissue repair. Fibrogenesis Tissue Repair. $2011 ; 4: 21$

126. Jenkins R, Burton N, Cooper R. Effect of manuka honey on the expression of universal stress protein A in meticillin-resistant Staphylococcus aureus. Int J Antimicrob Agents. 2011;37(4):373-376.

127. Jull AB, Rodgers A, Walker N. Honey as a topical treatment for wounds [review]. Cochrane Database Syst Rev. 2008;4:CD005083.

128. Jull AB, Cullum N, Dumville JC, Westby MJ, Deshpande S, Walker N. Honey as a topical treatment for wounds [review]. Cochrane Database Syst Rev. 2015;3:CD005083.

129. Bardy J, Slevin NJ, Mais KL, Molassiotis A. A systematic review of honey uses and its potential value within oncology care. J Clin Nurs. 2008;17(19):2604-2623.

130. Vandamme L, Heyneman A, Hoeksema H, Verbelen J, Monstrey S. Honey in modern wound care: a systematic review. Burns. 2013;39(8): 1514-1525.

131. Brölmann FE, Ubbink DT, Nelson EA, Munte K, van der Horst CM, Vermeulen H. Evidence-based decisions for local and systemic wound care. Br J Surg. 2012;99(9):1172-1183.

132. O'Neill J. Antimicrobial resistance: tackling a crisis for the health and wealth of nations. Rev Antimicrob Resist (Lond). 2014:1-22.

manuscript management system is completely online and includes a very quick and fair peer-review system. Visit http://www.dovepress. $\mathrm{com} /$ testimonials.php to read real quotes from published authors. 